\title{
Synthesis of $\mathrm{MnCo}_{2} \mathrm{O}_{4.5} /$ graphene Composite as Electrode Material for Supercapacitors
}

\author{
Yanhua Li, Xiahui Peng ${ }^{*}$, Jialian Xiang, Jiaxin Yang \\ Hunan Province Key Laboratory of Applied Environmental Photocatalysis, Changsha University, \\ Changsha 410022, China \\ *E-mail: pxiahui630527@126.com
}

doi: $10.20964 / 2017.11 .63$

Received: 31 July 2017 / Accepted: 12 September 2017 / Published: 12 October 2017

\begin{abstract}
$\mathrm{MnCo}_{2} \mathrm{O}_{4.5} /$ graphene composite is obtained by a simple hydrothermal method. The as-synthesized $\mathrm{MnCo}_{2} \mathrm{O}_{4.5} /$ graphene composite is characterized by $\mathrm{X}$-ray diffraction, and scanning electron microscopy. Electrochemical property of $\mathrm{MnCo}_{2} \mathrm{O}_{4.5} /$ graphene composite is carried out by cyclic voltammetry, galvanostatic charge-discharge and electrochemical impedance spectroscopy. $\mathrm{MnCo}_{2} \mathrm{O}_{4.5} /$ graphene composite exhibits good supercapacitive performance. The specific capacitances of $\mathrm{MnCo}_{2} \mathrm{O}_{4.5} /$ graphene composite at $5 \mathrm{mV} \mathrm{s}^{-1}$ and at $0.5 \mathrm{~A} \mathrm{~g}^{-1}$ are 255.8 and $252.3 \mathrm{~F} \mathrm{~g}^{-1}$, respectively. $88.7 \%$ of the specific capacitance is retained for a 16-time current density increase, indicating its superior rate capability. At the 1000th cycle, $\mathrm{MnCo}_{2} \mathrm{O}_{4.5} /$ graphene composite shows a specific capacitance of $225.6 \mathrm{~F} \mathrm{~g}^{-1}$ at $1.0 \mathrm{~A} \mathrm{~g}^{-1}$, which is $92.6 \%$ of initial specific capacitance, demonstrating its excellent cycling stability. These characteristics illustrate that $\mathrm{MnCo}_{2} \mathrm{O}_{4.5} /$ graphene composite is a promising electrode material in supercapacitors.
\end{abstract}

Keywords: Supercapacitors, $\mathrm{MnCo}_{2} \mathrm{O}_{4.5}$, Graphene , Hydrothermal method

\section{$\underline{\text { FULL TEXT }}$}

(C) 2017 The Authors. Published by ESG (www.electrochemsci.org). This article is an open access article distributed under the terms and conditions of the Creative Commons Attribution license (http://creativecommons.org/licenses/by/4.0/). 